AnNa PRzYTOMSKa-La Civita

Adam Mickiewicz University

\title{
Apus: Non-human persons in the ontology of the Q'eros from the Cordillera Vilcanota (Peru)
}

Pues dime hermano, como as puesto tu esperanza en una piedra, como si fuera Dios verdadero; no ves que esa piedra no tiene entendimiento para conocer lo que le pides? No ves que no tiene voluntad para amarte, no ves que no tiene ojos para verte, ni oydos para oyr lo que le pides, ni boca para consolarte, y si supiera hablar, te dixera: Indio, loco estás, ciego estás, pues has puesto tu esperanza en mi, que no tengo poder alguno, ni te puedo dar nada de lo que me pides; no ves, que soy piedra, que los pájaros y las zorras, se ensucian en mi, si soy piedra, como tu lo ves, como puedo ser Dios? Porque las piedras son muchas ... y Dios verdadero es uno solo.

Hernando de Avendaño, Sermones de los misterios..., sermón III, p. 27. (1648)

\section{Introduction}

Tn November 2013, when I was getting ready to start my fieldwork among the Q'eros in Collpacucho village (Peruvian Andes), Francisco, my Q'ero guide, warned me that I would have to perform the haywakuy ritual, and prepare myself accordingly ${ }^{1}$. He explained to me that the ritual should be addressed to apus (mountains) to greet them and ask for permission to stay in the village. He said:

\footnotetext{
${ }^{1}$ This paper is based on field research carried out as part of the research project (No. 2014/15/N/ HS3/01694) titled "Andean ontology in anthropological approach. Study of indigenous concept of 'human-nature' relationships on the example of Quechua community of Q'ero, Peru". The project was financed by the National Science Center in Cracow and was carried out between 2015 and 2018.
} 
Cuando llegas a la casa de alguien, tienes que tocar la puerta, pedirle permiso para entrar y más bien venir con algo para el dueño, ¿cierto? Lo mismo sucede en el caso de los apus [When you come to someone's home you have to knock on the door, ask for permission to enter, and it's best to come with something for the host, right? The same thing goes for the apus].

Even before I came to the village, I noticed that the mountains were very important beings to the inhabitants of the Peruvian Andes, who treat them as persons. As it turned out later, the relations between the Q'eros and the apus, and the haywakuy ritual became the central points of my research in that community.

The Q'eros are a Quechua-speaking community residing in the Vilcanota mountain range in Peru (Cuzco Region). Their territory is divided into five villages: Hatun Q'eros, Marcachea, Quico, Totorani, Hapu. They practice agriculture (potato, maize), herding (alpaca, lama, sheep, cow) as well as weaving for their own use and for sale. The Q'eros are also known for shamanic practices aimed at ensuring their wellbeing. The climate of Q'eros territory is characterized by two seasons (rainy and dry) and three ecological zones (ranging between 1800 and 5000 metres above the sea level): yunga, qeshwa, puna - from moist jungle to snow-capped mountain peaks. Until the 1950s, the Q'eros had lived in cultural and geographical isolation from the majority of the national society. However, over the past 15 years, we can observe their growing migration to urban agglomerations: mainly Cuzco and nearby pueblos: Ocongate, Paucartambo. The causes of migration may lie in the construction of roads, which facilitated transport to urban areas, but above all: in the desire to improve living conditions (work and education) and escape climate change (which negatively affects pastoralism and agriculture). It is also important to note Q'eros's participation in "mystical tourism" and the increasing influence of the Maranatha Church.

In this paper I wish to contribute to current anthropological debates on human and non-human relations in the Andes. The purpose of this text is to show how the Q'eros understand the concept of apus and what is the relationship between these two types of beings. Based on my fieldwork, I conclude that the relationships between Q'eros community and apus take a twofold form: reciprocity (ayni) and predation, which are expressed in terms of feeding (mutual or feeding someone else with self). In my paper, I also describe one of the most important ritual practices - haywakuy - which reveals how Q'eros use the concepts mentioned above in everyday life.

In Quechua 'apu' means 'sir'. This term was translated by anthropologist in many ways: "holy mountains" (montañas sagradas), "mountain spirits" (espirtus de las montañas), "angels of nature" (angeles de naturaleza) or "guardian beings" (seres protectores, divinidades tutelares). There are many studies devoted to this subject, which remain relevant despite the passage of time. Pioneering ethnographic works on apus describe these entities as: masters of precious metals and wild animals (Fuenzalida 1965; Favre 1967; Casaverde 1970; Martinez 1983), sky and weather deities or agricultural deities (Isbell 1978). 
Colonial sources portray apus as origin points of deities and people, the so-called pakarinas (Zuidema 1977). In some regions of the Andes, apus are identified with ancestors, which is expressed through kin terms: tayta (father) and machu (grandfather) (Mendizábal 1989: 62-63; Gil García 2008: 106) or machulas (ancestors) (Gose 2006: 31). Apus are also conceptualized as "holy places", i.e. wak'as (also huacas) - places of worship, where rituals are performed (Sánchez 1999; Astvaldsson 2000). Moreover, apus are closely related to shamanic practices. Firstly, because the shamanic initiation is usually carried out on mountain peaks (Fernández 2004). Secondly, all shamanic practices are based on a close and intimate relationship between apus and altomesayoq (shaman) (Tomoeda 1992; Ricard Lanata 2007; Przytomska 2017). Rituals related to apus, called haywakuy, are carried out by shamans to ensure a bountiful harvest and reproduction of domestic animals, as well as good health and happiness for inhabitants (Rösing 1995; Abercrombie 1998; Gose 2001; Przytomska 2017).

Many of researches (e.g. Martinez 1983; Marzal 1983, 1985; Sánchez Garrafa 2015; Saldaña Sousa 2017) define apus as Andean gods or guardian deities who protect people (protection scheme). For example, Rodolfo Sánchez Garrafa (2015: 15) claims that "apus is a term that is used to describe ghosts inhabiting the mountains", thus presenting a popular interpretation similar to the traditional concept of animism (by E.B. Tylor), which describes inanimate elements of nature (e.g. mountain) as inhabited by spiritual beings. Researchers who represent a similar perspective in their definitions of apus distinguish the spiritual (apus as a spirit) and material (the mountain as a material form) substrate, i.e. the spirit or deity dwells in a mountain, as the soul dwells in a human body. I consider this interpretation to be insufficient to define the phenomena from the Andean cultural context. This paper adopts the perspective brought by the ontological turn, which is also represented in anthropological studies conducted in Andean region by M. de la Cadena (2015), C. Allen (2016), J. Alderman (2015) or M. Sax (2011). This perspective defines apus as non-human persons, which together with humans and other non-human beings (i.e. machulas - ancestors) formed ayllu, which "is a ubiquitous term in the Andeanist ethnographic record, usually defined as a group of humans and other-than-human persons related to each other by kinship ties, and collectively inhabiting a territory that they also possess" (de la Cadena 2015: 44).

Marisol de la Cadena (2015) uses the term Earth Beings to describe apus, translating tirakuna to English. Tirakuna is a combination of Spanish word tierra (Earth) and Quechua plural morphem - kuna. De la Cadena explains that the term refers to mountains, rivers and lakes as personal beings. However, during my fieldwork among the Q'eros, I observed that tirakuna was also used in another context - referring to pachamamas (earth-persons), not to apus. Considering these terminological inaccuracies, I propose to introduce a new term - mountain-persons, which in my opinion is closer to the original meaning of this word. In the following sections I present the usage of this terms among the Q'eros. 


\section{Nature-culture in anthropological approach}

Nature has been present in anthropological discourse practically since the beginning of this discipline - in folklore studies, cultural ecology, studies on myths and rituals etc. (Descola, Pálsson 1996: 1). For instance, nature was granted a special place in structural anthropology, because 'nature-culture' dichotomy was considered a universal concept for all cultures (Lévi-Strauss 1964, 1972). In western philosophy since Classical times, humans have been set apart from all other animals and the Cartesian schemes of nature-culture and body-mind have until recently been one of the most important anthropological assumptions (Howell 1996: 126-127). This dualistic and anthropocentric view, with its roots in the Platonic (dialectical pairs) and Judeo-Christian (human privilege) traditions, has become a dominant principle in European scholars' thinking about nature. However, since the 1970s and 1980s, this paradigm was challenged, also from within (Roset 1973; Horrigan 1988; Willis 1990; Milton 1993; Latour 1994). Studies on the non-European peoples (e.g. Hallowell 1976; Strathern 1980; Descola 1986, 1992, 1996; Ingold 1988, 1993; Viveiros de Castro 1992; Århem 1996; Rival 1996) proved that these dualistic patterns are not universal for all cultures, differences between cultural and natural reality are fluid, and the concept of nature is also culturally and historically constructed.

Studies focusing on cultural ecology have given rise to questions concerning the ontologies of non-European peoples, and within these - the relationship between nature and culture. Many researchers have also attempted to break with naturalistic (Western) analytical tools, redefine existing assumptions and develop a new conceptual apparatus. Based on research, anthropologists concluded that in non-European ontologies nature is a personified part of the reality with which humans establish a network of social relationships. This finding has led to further conclusions: first; what is considered in Western naturalist ontology as material or natural reality (animals, plants, mountains), in non-European ontologies is endowed with personhood - that is why nature cannot be defined here in opposition to culture, but as part of it; secondly, in connection with the "nature" being person-like, the concept of personhood had to be further elaborated.

\section{The concept of person and agency}

Non-human persons are directly related to what the naturalism conceptualizes as "nature" or "natural environment" (hills, lakes, plants, animals, etc.) and as "supernatural beings" (dead, ghosts, demons, etc.). In our (naturalistic) ontology, these elements of reality are understood as non-personal entities. However, according to Q'eros ontology, these beings are similar to people, i.e. have such qualities as intentionality, personality, free will, thoughts, desires, emotions, etc. Inge Bolin (1998: 43) wrote: 
The Andean people do not separate the natural from the spiritual environment. They believe that, like animals and people, all elements of nature live, feel, and breathe. Pachamama, the Apus, lakes, rocks, springs, and animate and inanimate beings - all aspects of nature need food and drink, love and consideration.

One of the main elements of Q'eros ontology is that all aspects of the material reality are alive, person-like and agentive, and the lives of Andean people are associated more or less with non-human beings. Their presence is evident in such aspects as: agriculture, shepherding, weaving, health and treatment, dances and music and mobility ${ }^{2}$.

In non-naturalistic ontologies, non-humans are similar to humans (Descola 1996: 85). The ontology of the world composed of human and non-human persons is organized according to the sociocentric principle. Studies of non-European communities have shown that non-human beings, such as animals, plants, atmospheric phenomena, ghosts, the dead, rocks, etc., are, just like humans, endowed with agency, logical and reflective thinking, feelings, intentionality and an ethos similar to that valued by humans. A. Irving Hallowell (1976) was the first to use the term "non-human persons" to describe these entities, after which the term was incorporated into cultural anthropology. Researchers such as Philippe Descola (2015) and Eduardo Viveiros de Castro (1992), or Eduardo Kohn (2013) showed that Amazonian ethnography challenges our concepts about life and our ways of thinking, in such way that we need to rethink the ontological status of non-human beings. Henceforth, many anthropological works have begun to reveal the agency and personhood of non-human beings in cultures on all continents. Starting from the anthropological concept of non-human persons, I present a detailed description and analysis of ontologies of apus that formed the social reality of the Q'eros.

Relationships between humans and non-humans in Q'eros ontology are shaped by two types of relations: predation and reciprocity (exchange). My analysis is based on the concepts of reciprocity and predation as elaborated by Philippe Descola in his book Beyond nature and culture (2013), where he claims that practices and behaviors of each community reveal the regularity, continuity and a certain degree of automatism that constitutes the basis for (often unconscious) relationship models that form different elements of reality. Descola distinguishes 6 types of relationships that seem to play a dominant role in personal connections: reciprocity, predatory, gift, production, protection and transmission. In this text, we present the characteristics of the first two types, which characterize the relations between humans and non-humans in Q'eros ontology. The relationship of reciprocity and predation consists in the transfer of values (soul, vital substance, etc.), which circulate between beings of the same ontological status. Descola explains:

\footnotetext{
${ }^{2}$ In the context of another Quechua groups, see: (Allen 1988, 1982; Gose 1986, 1994; Bolin 1998; Stobart 2006).
} 
The first relationship, that of "exchange," appears as a symmetrical one in which any agreed transfer from one entity to the other requires something in return. The other two are asymmetrical. In the first one, entity A takes something of value from entity B (perhaps its life, its body, or its interiority) without offering anything in exchange: "predation" is what I call this negative asymmetry. In the other, entity B offers something of value to entity A (maybe even itself) without expecting any compensation: I call this positive asymmetry "gift." At least two of the terms that I use to qualify these relations have a long anthropological history, so I need to specify their meaning in relation to previous definitions.

Predation is an example of the productive destruction necessary for the survival of an individual, so it is not related to cruelty or desire to kill another. On the contrary - it transforms the sacrifice into an object of the greatest importance for any being that eats the sacrifice. Predation is a mechanism necessary for predator's survival.

\section{Apus as non-human persons}

"Apukunata runakunahina kanku/Apus are like people" - the Q'eros have explained to me many times. One time I asked: "Apukunata runakuna kanku?/Are apus people?" - but they responded negatively. The inhabitants of Vilcanota mountain range claim that apus are similar to humans but are not humans. Particular attention should be given to morpheme hina, which in Quechua means similarity and comparison, not equivalence. The similarity is due to the fact that apus, just like people, are characterized by agency and subjectivity, have emotions, specific personalities, free will, intentionality, and intelligence. According to the Q'eros, apus form families - they have spouses, children, and also lovers (e.g. Antipukara is the husband of Phalchani, Marcachea village). They can establish political alliances and lead wars (e.g. Ankashchaki). They eat and drink (have whims and favorite foods) ${ }^{3}$, they argue ${ }^{4}$, rest, organize games and parties ${ }^{5}$. They can be distinguished into female gendered ones (e.g. Ñañantiyoq, Phalchani) or male gendered (e.g. Ausangate, Wamanlipa, Ayawiri). The Q'eros' knowledge about an apus' gender comes from the stories of the ancestors, but also from observing the size and shape of the peaks. Smaller and gentler mountains are women, larger and steeper ones are men. In Andean culture, apus conduct a human-like life, have personal traits and needs, form families and clans, and there are bonds of kinship and affinity between them (Valderrama, Escalante 2012). They have sexual relationships between themselves, but also with shamans (Rosas Lauro

\footnotetext{
${ }^{3}$ Other examples see also: (Gil Garcia 2012: 46; Valderrama \& Escalante 2012: 39).

${ }^{4}$ The story about apus war from Cotabambas village (Valderrama, Escalante 2012: 39) and another story about quarrel between Ausangate and Sayriyuq (Ricard Lanata 2007: 323).

${ }^{5}$ Rozas Álvarez (1992: 210) describes a similar story from the Cusco region.
} 
2014: 42-43), which is part of the shamanic initiation. Rozas Álvarez (1992: 208) describes the experience of a shaman who got married to an apu:

Since I got married with an $a p u$, we walk together everywhere with my altar to heal the sick. Once, the apu told me in a dream that I must be a maid to get married to him. But I got married with a man and after a few years my husband became seriously ill and died. That's why I say that the apu is very jealous, he was jealous of my husband and took him away from me. After the death of my husband, I didn't remarry and maybe that's why the apu gives me the power, I can heal very sick people, even those for whom doctors no longer see any chance. [Translated from Spanish by the author of the present article.]

Apart from the fact that apus have different genders, they may also differ in the functions they perform, because they have their own internal hierarchy. This is explained by the following quote:

There are different apus. Some apus are shamans, so if they choose you, you will be paqo. And if this apu is powerful, you will be a great altomesayoq. For example, my apu is Ausangate, he is a great altomesayoq, he is the guardian of my whole family. But there are also other apus, doctors, lawyers, politicians (...) There are different apus. We say awki or collana for mighty mountains, more sacred, higher, where people don't reach. Then, there are payan, their functions are slightly weaker, no? Awki and collana are mountains that no one can reach, payana are lower and closer to villages, cayao are near villages. For example, Pachatusan and Wanakawri are cayao, they are guardians of the villages. They are together with people, focused on people and animals. Payan are different, they are more connected with ghosts, with birds. And collana are associated with the stars, with the sky and with the sun. These are the strongest apus. Apus have different forms, just like us, how teachers have ... their levels, primary school, high school, no? Different levels. And as part of the collana, there are awki - it means bosses, just like Ausangate. Payan is a messenger of collana. Payan informs them what is going on in the villages, collana sends payan, payan sends cayao and, in this way, they communicate. They are like grandparents, they have a lot of knowledge, that is why they lead us. Awki are connected with Hanan Pacha [the upper world], they know what will happen this year, they already know. [Jorge, Q75, Quico]

According to Jorge from Quico, apus are omniscient, which distinguishes them from people. Another shaman, Toribio from Hatun Q'ero, also confirmed that apus know the past, present and future. This quality of apus is used by shamans in kuka qhaway (coca divination ceremony). Toribio also claimed that apus speak in all languages:

they speak in English, Polish, Spanish, Quechua, all languages, no problem. They know everything about you, about your family, you only tell them what the names 
of your grandparents are, you parents, brothers and they will tell you everything, whatever you ask, if they are sick or healthy, if they need a haywakuy. They come as ghosts, or birds, not as people, without a body, you can only hear their voice ... [Toribio, Q69, Hatun Q'ero]

According to the Q'eros, inside the apus there is an underground world consisting of cities and villages where normal life thrives. On the mountain slopes there are secret entrances (punku) - portals that allow passage into the interior. The Q'eros from Quico said that one of the punku is located on the slopes of the nearby Osonaku apu. Victor and Manuel told me that the story recounted below "happened a very, very long time ago. There were a woman and a man, a marriage, they were not ordinary people, they were altomesayoq". Victor said that these people went to the top of Osanaku in search of a cow that escaped a few days earlier. To reach the top, they used the punku, whereby they transported themselves to the top of the apu. Since they were shamans (altomesayoq), they knew the location of the punku and knew how to use it. Then, a thunderbolt (illiapa) struck them at the top of the apu, turning them into rocks. Until today, they are enchanted, turned into a stone, and constitute one of the most important $w a k^{\prime} a$ (power spot) for the Q'eros from Quico. The Q'eros' accounts indicate that gold deposits are located near this place. The spot is considered to be "enchanted", because anyone who approaches this place dies, disappears in unknown circumstances or is prevented from looking for precious metal by a sudden storm.

\section{Apus as the guardians of the villages}

As already mentioned, one of the basic functions of apus is protecting villages. Around every village there are several local apus, who are considered to be community guardians, mamas and taytas (mothers and fathers). The following statement reflects the Q'eros' notion of apus:

Nañantiyoq is a very important $a p u$ in Quico. It is a guardian of residents, who looks after crops, animals, this is her role ... She is callao [apu status]. She is a woman [warmihina]. He has 3 tops, that is why they say they are sisters [ñañay in Qeczua is a sister]. The first sister looks after people, the second sister looks after harvests, and the third sister looks after animals and fertility. [Victor, Q62, Quico]

Antipukara is the son-in-law of the village. He was not from here. He was invited to move in by another apus, he married Phalchani, he came here from Puno, from Qollas. Other apus invited him from there. And he came here, my grandparents said ... He came here to protect people from storms, from everything, they say that he is omnipotent [munayniyoq]. Grandparents said that inside Antipukara there is a gold city. The altomesayoq entered inside and brought gold with mules. It was a long time ago, paqos said so ... [Juan, Q48, Marcachea] 


\section{Can you live without apus, if you want to have good crops?}

No, it's very difficult. To have a good harvest you must always be in a relationship with them. They are the rulers of animals and crops. Paqos can talk to them, listen to their messages. [Toribio, Q67, Hatun Quico]

We see that the role of apus is to protect people and to look after their health and well-being. The protective function of the mountain-humans is revealed when outsiders come to the village, e.g. an anthropologist. When I was in the village for the first time, or I came back after a long absence, the Q'eros told me to perform the haywakuy ritual to ask for permission to stay. The Q'eros explained to me that apus do not know me, so I have to introduce myself and tell them what the purpose of my stay is.

Cuando llegas a la casa de alguien tienes que tocar la puerta, pedirle permiso para entrar y más bien venir con algo para el dueño, ¿cierto? Lo mismo sucede en el caso de los apus [When you come to someone's home you have to knock on the door, ask for permission to enter, and it's best to bring something for the host, right? The same goes for apus.]

- shaman Francisco explained to me when I first appeared in Qollpacucho village (Hatun Q'ero) in December 2013. The following quote from my fieldnotes also refers to this concept:

We are about 6 hours away from the village of Huchuy Quico. We came here to collect potatoes. They are digging them out, I and the kids help to collect them and throw them into the sack. Manuel [paqo] tells me that I am not from here, so I have to greet with apus and pachamama before I go to sleep, so that I do not get sick, [I need to] ask them to protect me. Yesterday, when Manuel and I went from Hatun Quico to the neighboring village - Huchuy Quico, I joked. Manuel gave me $k^{\prime}$ intu and told me to do phukuy to greet the apus and ask for a good trip. I smiled and said: "You are the shaman, I do not believe in it anyway, so apus will not listen to me. Do it yourself". As soon as I finished speaking, I felt an impact from the side. Manuel pushed me. I fell to the ground. The stone was falling in my direction. It was a strange event. Manuel said seriously: "you see, you can't make jokes about the apus, they are offended, take a coca and make phukuy". [Fieldwork dairy, April 2016, Kiko]

Manuel stated that the falling stone was an intentional action of apus: the mountains-persons, which were offended by my ironic commentary, decided to teach me a lesson. Manuel asked me to adapt to the local customs, otherwise the things might go wrong (illness, death or accident). The Q'eros believe that traveling to unknown places is always fraught with danger. Moving around, a person enters an untamed area - a unknown space with which (or with whom) one has no relations. For this reason, the Q'eros always carry coca leaves, so that 
they can greet the apus they encounter on their journey. Any problem or accident that happened during the trip was caused by the unfavorable action of the apus. The following events, in which I participated, took place in March 2016; they demonstrate how the Q'eros understand failure or accident while traveling:

March 11, impatient as the Q'eros did not contact me, I decided to go alone to Marcachea village. I took the essentials - clothes, food and a sleeping bag. March is still rainy season, so I prepared for a possible storm, fog and mud. The trail to Marcachea is quite difficult, due to the dense fog and mountain passes. Nevertheless, I knew the trail well and decided to take the risk. A friend brought me to Picotayoq - from where I started my trek to the Q'eros village. The road, even though muddy, was not so terrible. Unfortunately, after a 2-hour hike, I encountered a thick fog. I lost sight of the reference point - the Escalera peak. (...) Suddenly the path ended, three hills appeared in front of me. I was confused, I did not know where to go, I chose the wrong way, and had to go back to find the right path. Then the fog subsided, and I could see Escalera again. I made a break, and when I started my journey again, the fog returned, even thicker than before. Nature seemed to be playing with me. I was looking for another point of reference, the stone with a skull of the bull on top, which was the way the Q'eros marked their paths here. I reached Escalera apu and started to look for the pass. I wandered for another 3 hours and I didn't know where I was. It was late afternoon, so I decided to turn back. I didn't see anything, so I decided to go down towards the valley. When the fog thinned, I noticed the river. Going down, I found out from river current that I was on the opposite side of the valley, I made a big circle. Exhausted, I was heading towards Picotayoq. I couldn't get there before dark, but I found an abandoned hut made of stones where I spent the night. In the morning, on the trail I met Juan from Marcachea, who was coming back from Paucartambo, and I told him what happened. After listening to me, Juan asked: "did you ask [apus] for permission?" “I didn't ask" - I replied. "Escalera didn't let you go. You are a stranger, not from here, never travel alone through the mountains, you have to do phukuy, you must ask for permission."

The Q'eros from Marcachea village said that the apus had intentionally sent the fog, so that I could not get to the village, because, first - I was a stranger, and secondly - I had failed to ask for permission to travel and enter the village. Travel complications or accidents are understood by the Q'eros as intentional actions of apus and the consequence of a breakdown of order. The above excerpts from my fieldnotes show that, according to the Q'eros, I behaved incorrectly. In the first case, I refused to pursue phukuy, mocking the shaman and the apus. The consequence was a falling rock. In the second case, I went to the village alone and did not ask for permission. As a result, the apus sent thick fog and made it impossible for me to continue my journey.

Another example of an apus' intervention in the Q'eros life comes through the tragic story that took place in November 2015. Before the end of the year, 
there were guests - relatives of the Q'eros, who moved to Lima (married couple and their 11-year-old son) - coming to the Marcachea village:

The host family organized a party, which was also attended by other members of the village. The Q'eros ate, danced and drank large amounts of alcohol. At night, when everyone was very drunk and went to sleep, a tragedy occurred. Parents left the 11-year-old boy in a hut, in which Victor's motor was turned on. The child was poisoned by toxic fumed and died. Victor was partly blamed for the death of the child, because he is the owner of the motor, he also participated in the feast and forgot to turn off the engine. According to the inhabitants of Marcachea village, Victor is a trouble maker - he gets drunk and abuses his wife and children every week. Victor, who was afraid of possible consequences of the child's death, decided to escape from the village that same day. When Victor reached the pass at the top of the Escalera, he lost his strength. He could not march further and decided to return to the village. Residents commented on this situation, saying that Escalera decided to stop Victor, not allowing him to escape to the city. [Fieldwork diary, November 2015, Marcachea]

There were no consequences for Victor, and the next Saturday, one week after the boy's death, he got drunk again. It is noteworthy that the Q'eros did not take into account the circumstances of the situation (e.g. alcoholic intoxication, stress and fear), which could have influenced Victor's physical condition. For the Q'eros, his lack of strength was caused by the action of apus, who in the light of these tragic events did not let him leave the village. The protective function is part of the general order kept between people and non-humans. According to the Q'eros, people are obliged, among others, to feed the local apus. Discontinuation of these practices has specific consequences. Victor from Quico explained:

They [apus] are like grandparents, they know a lot, they are our guides. Awki are connected with Hanan Pacha [the upper world]. They know what will happen this year. They help us, they serve us. Everyone has their own mountain, they are like my mother, my father. It is like my father or mother, as humans - grandparents used to say so. Each person has a mountain since times of our ancestors. For example, the blood of the Samata family... my family has their own apu, Kikukuchu, this is also apu of Maria Apasa. She, her mother and her grandmother addressed this apu. He's like their father. Every apu looks at the family, what is their way, how they behave. If they are behaving badly, they may get punished, many people were punished by apus and that is why they didn't have good harvests, no production, they lead a sad life, their animals are dying ... It is difficult, when you leave the mountain [abandon ritual duties], you stay alone. They are offended [...] their anger can even strike the whole village, people and animals can get sick. We wrong them [without providing haywaku], so they punish us. It is due to apus that people have harvests, because who gives rain? Sometimes people say, "what a crazy rain!" But it is not like that, they do not understand 
why this is happening. They do not know where diseases come from. Quico has changed a lot, half are brothers [Maranatha]. This is a problem for everyone. [Victor, Q79, Quico]

The above quote testifies to the fact that every human being is connected with a specific $a p u$, who chooses a person right after birth. In addition to the guardian apus, there are also local apus connected with the place of residence of a given person. The service that Victor is talking about is not, however, part of a one-sided relationship. It should be noted that Victor (Q79) indicates that he serves apus, but apus also serve him. In fact, we are dealing here with acts of mutual care. People feed and protect their apus, and the apus protect people and their villages. The disruption of this order based on ayni (reciprocity), for example as a result of conversion to the Maranatha church and the renunciation of ritual practices involving non-human beings, leads to the failure of relations with them. Ayni, a fundamental form of reciprocity, has also been dubbed as the ethos of Andean indigenous culture. Catherine Allen (1997: 78) commented that ayni, at the most abstract level, is the give-and-take rule that governs the universal circulation of vitality:

It can be positive, as when brothers-in-law labor in each other's fields; or it can be negative, as when the two men quarrel and exchange insults. This circulation be it of water or human energy - is driven by a system of continuous mutual interchanges, a kind of dialectical pumping mechanism.

Every class of being takes part in this cosmic circulation. Andean people maintain interactive reciprocal relationships not only with other humans, but with their animals, their houses, their potato fields, and with different categories of non-human persons.

\section{Apus as masters of wild animals}

Apus also play the role of rulers of wild animals. The story told by Nicolas refers to historical events - to the war on the Pacific Ocean, which took place in 1879-1884. According to the Q'eros, apus Ausangate, Ankaschaki, Wamanlipa and Wayruruni participated in the fighting, helping the Peruvian side. Nicolas from Esparilla said:

It was in the times of Andrés Avelino Cáceres, during the War for the Pacific, in other words, not so long ago... Andrés Avelino Cáceres was a general and fought with the Chileans ... and the Peruvians almost lost Tacna, Antofagasta, Arica, even more [territories]. Andrés Avelino Cáceres came from the Andes and because of that he managed to contact the altomesayoq from Ausangate region, so the altomesayoq arranged a meeting with the apus. During this meeting, Ausangate, Ankaschaki, Wamanlipa and Wayruruni came to help in the war. These apus 
are the bosses and masters of wild animals, so Ankaschaki has let out almost a million vicunas. Andrés Avelino Cáceres set up a poncho for all vicunas. This is not a fairy tale, it is true. [Chileans] They thought they were people, but they were animals. Ankaschaki and Ausangate also sent an army of birds - qaques and chuanqueres, black birds with large beaks. So, they sent millions of animals. When the Chileans saw that many, many people were coming, they gave up. And they sent a document with a peace treaty. And they signed this document. The apus took part in this war. And Andrés Avelino Cáceres is today known as the wizard of the Andes [el brujo de los Andes]. [Nicolas, W15, Cuzco]

A similar story can be found in the autobiography of Gregorio Condori Mamani, recorded and written down by Ricardo Valderrama and Carmen Escalante (1979). In her book, Marisol de la Cadena (2015: 97) also mentioned the participation of Ausangate apu in the fight between the Indians and hacendado (landowner) and the apus participation in independence battles against the Spaniards and in the war of the Pacific. This means that the story is widespread in the Cusco region. Apus, on the request of altomesayoq (shamans), help the Peruvian side in the fight against the Chileans, sending on wild animals - birds and vicunas. However, this is considered to have been an exceptional situation, and access to apus resources is limited ${ }^{6}$.

When a man kills the apus' animals without their permission, he exposes himself to anger and punishment from those non-humans. Gabriel Martínez (1983: 87) pointed out to the twofold side of the apus, claiming that they may be either friendly or hostile, and that their behavior depends on the human attitude. Therefore, the behavior of the mountain-person is a reaction to human actions. The following story illustrates the predatory behavior of apus towards the Q'eros, and its context:

In Qompipamapa [literally: beautiful place] there was a wild animal ... it was wild, so one of villagers said: let's go catch him. And they went to catch this bull. Casimiro Espinosa went there, he gave the order. He was then a man in the prime of his life, from Marcachea. They brought the wild bull. So, this animal became their property in this way. But they did not have permission, it was an animal that belonged to Qompipampa. It was enchanted, it was not a real animal ... Inside the Qompipampa there are many enchanted animals. They did not catch a normal animal, but an animal of the apu. It was the Qompipampa's spell. And they caught the bull and killed him. There were two apus. At night, the apus talk to each other... So, people slept in a cave, fell asleep after dinner and then

\footnotetext{
${ }^{6}$ Another story says that after the Spanish conquered Cusco, ancestor of the Q'eros fled to the high mountains, finding refuge in the Vilcanota mountain range. Spanish conquistadors sent a group of soldiers following them. According to the story, the Spaniards only reached the place today called Pukalloqlla (a place on the way to Hatun Q'ero). The Q'eros say that the apus killed Spanish soldiers in this place, by dropping heavy rocks from their slopes. The name Pukalloqlla literally means the "red flood" (the earth and rocks here have a red-orange shade).
} 
the apus talked to each other. The elder to the younger [Agosto indicates a hierarchy of apus]. The elder says, "This bull is called Runtupuku, who killed him? Who stole our Runtupuku?". Another says: "They killed our white bull. He was all white". Then they asked again: "Which one of our animals is missing? What happened to our bull with a white color? Who took him? Where?". Paqos [shamans] from the Q'eros village heard these conversations. The apus said: "You have to look for him. We'll go find him right away". The one who caught the bull was the head of the village [kamachikuq]. As the apus said, they went to look for him. Then the head of the village died, at once, in the cave. Qompipampa, the owner of the bull, killed him. [Agosto, Q87, Esparilla]

The story recalled by Agosto tells about tragic consequences of breaking the arrangement between people and non-humans - the appropriation of the bull caused the death of the perpetrator, as punishment for killing a wild animal. For these reasons, the Q'eros are usually wary of catching lost or wild animals, because they are not sure if the animal escaped from another village or whether it belongs to apus. The punishment for killing an animal may be death, disease, crop failure or death of one's animals. The Q'eros comment that apus are jealous of their animals and only shamans can receive them as a gift:

Vicunas do not have owners [people], same as taruka, fox and puma, which are animals belonging to apus. Why pumas eat llamas or alpacas? Because apus tell them: run, eat these animals. And sometimes people get angry and kill the puma. And then the mountains become even more agitated or get offended. These [wild] animals also serve altomesayoq, awki send out condors or pumas. They send their children [animals], for example a condor, and he says [to paqo]: "I am the son of this apu, I am a messenger, or I am a guardian", that's how they talk.

\section{In a human voice?}

Yes. In a human voice, they come to convey a message. For example, paqo calls his apus, and he sends his animals, birds or pumas, and they talk.

\section{But they come as animals?}

No, as ghosts, you can't see them, but you can hear them and feel them. You can't see such things. It is very strong, you can die, if you see it you can die. [Victor, Q80, Quico]

\section{Apus as masters of precious metals}

According to the Q'eros, not only wild animals are the property of apus, but also precious metals, which, like human blood, flow through the veins of the earth. For this reason, the Q'eros argue that no one can appropriate gold or silver without the permission of apus. The Q'eros from Quico tell a story that took place in the 1990s. A man named Mallki (non-Q'ero) heard about a legend saying that there are gold deposits near Osanaku apu, on the lands of the Q'eros people. 
He was a very ambitious man and hungry for wealth, and that is why he decided to explore the land on his own. Well prepared and stocked with provisions, he went to the mountains. While he was searching for gold, something unexpected happened when he approached the place called Qollpayoq (in Quechua: the golden spot). Mallki disappeared and no one knew what happened to him. According to the Q'eros, Qollpayoq is a very dangerous place - when someone approaches, dark clouds and a strong wind and even a thunderstorm comes up. In Qollpayoq, there is a lot of venomous snakes (Tachymenis preuviana), which the Q'eros believe to be the gold guardians. "Las fuerzas encantadas no dejan entrar/Enchanted powers do not let you enter" - the Q'eros comment ${ }^{7}$. The following story describes similar events:

Mama Juana is located close to the Hapu community, it is the high mountain, where the helicopter fell, it transported gold, about $80 \mathrm{~kg}$. From Puerto Maldonado to Lima, no? And they flew this way. And the fog has gone down, the mountains are high, and they collided. This accident was caused by apus. They did not want gold to be taken away. If someone wants to take their gold, they behave like this, strong fog, heavy rain and wind. It was 2005 or 2006. They were from Chile. 5 or 6 people died. No gold crumb was found. Apus hid them. Gold and silver are pachamama's blood. In Hapu, people did not hear anything, they only were notified from Puerto Maldonado ... that the helicopter had fallen at this hour and never reached there. Then they started to search. It crashed here, on snow-capped peaks. It is bad to look for gold, it is very enchanted, it belongs to the apus, to the earth. You can't take gold for free, you have to pay. You have to give haywakuy or offer an animal. If we don't do it, we can die. Gold is very enchanted, they [apus and pachamamas] are very much in love with their gold. It is hard to pick it up. They see everything that you take. You have to make a good haywakuy to take it. Then you can take it, I can negotiate it, because I pay. [Jorge, Q61, Quico]

The above stories describe the aggressive action of apus towards people, if people violate the order, for example, by appropriating things that belong to non-humans. Ricard Lanata (2007: 54) calls the apus "those who order" (kamachiq - the one who organizes) social life and nature.

In the stories, the Q'eros talk about the haywakuy ritual that needs to be performed if a person wants to collect gold. Haywakuy is a ritual of reciprocity (Przytomska 2017), in Quechua it literally means: "give something to someone, receive something, invite, share". As a collective act, it is carried out on two important occasions. The Q'eros claim that in August (the beginning of the agricultural year

\footnotetext{
${ }^{7}$ But why should gold be found in such an inaccessible place and so far from the Cusco mountains? The inhabitants of Quico explain that in the Inca times, the Q'eros areas were crossed by Inca routes, which connected the mountains with the jungle, from where gold was extracted and transported to Cusco. When llamas and mules died on the way, the porters hid the gold near the trail, and according to legends, some of these hidden treasures are still found in the lands of the Q'eros.
} 
and the month of pachamama) Mother Earth needs to regenerate to be able to bear fruit the following year. "You have to feed Mother Earth so that she will not be hungry," say the shamans. The Q'eros explained that in August pachamama is open and "as a woman is ready for fertilization, therefore, before sowing or planting it should be fertilized with a haywakuy". Then, this ritual is also carried out during the carnival (puhllay), when the community asks for fertility and good health for animals (uywa chuway). The Q'eros also make individual haywakuy, at any time, asking for individual good health, happiness, love, work, and to avert adverse weather, animal diseases, crop failure, or during weddings, while building a new home, to prevent theft or loss, and to resolve disputes or conflicts. It is also performed when people want to hunt for wild animals or when they want to look for gold. Haywakuy is a meal for non-humans, who in the act of reciprocity grant humans their requests. As the Q'eros emphasize, the well-being of people depends on the well-being of these entities and vice versa, the prosperity of apus and pachamamas depends on the actions of people. These dependencies define the principles of reciprocity and exchange in a relationship that is revealed in the process of mutual feeding of people and non-humans.

When people stop feeding the apus, i.e. do not follow haywakuy rituals, the apus become predators. Near Marcachea village there is Ankashchaki apu, which formerly was dangerous (a predator) for the inhabitants - it caught breeding animals and small children and kept them in its interior:

There were animals, llamas and alpacas in these holes, but you could not catch them. (...) The rock opens and [apus] take them. It is like they have a door with a key and close it immediately. That is what paqos say. At one time, paqos said that apu Ankashchaki had a large, old rock and one day a girl danced on that rock. The girl was dancing and suddenly disappeared, the child disappeared. Ankashchaki was very dangerous. [Juan, Q48, Marcachea]

Apus sometimes open themselves, open their rocks. And they enchant cows or people. Sometimes cows come out, but you cannot take them. If you catch them, the apu will kidnap your woman or child in exchange. They say that there are cities inside the apus. They take these children there. [Benito, Q83, Quico]

Long ago the apu Ankashchaki used to be very bad, they say. They say this apu has a hole in his stomach, that it has a hole. Previously, he was very bad, malicious. He was very clever. This apu has a table, an altar, we'll go there later. There is such a large rock, flat like a table. And they say that there was a child playing, a small girl grazing her sheep nearby. And she got lost. The child was dancing at this table and disappeared. They say that she was cheated by Wiraqocha, an old man with a white beard who came to her. And he laid sweet bread on the table [chuta]. And the child ate the bread. He cheated her and he was very pleased with himself. The child left its sheep and disappeared. Apu Ankashchaki took them to his stomach, inside. He was a bad $a p u$, very dangerous, a cheater. But later the $a p u$ 
offered freedom to this child. But only after a year passed. They say so. This child said that there was a shop inside this rock, there was a lot of bread and sweets there. There was a city there. The child has returned, but I do not know. They say she came back as an adult. Now $[a p u]$ is no longer bad. Now he is gentle. Now we are going there [on the rock] and he is doing nothing to us. Earlier [apu] he wanted to take us, enchanted us, took our animals, our cows. It was scary. Then altomesayoq did a lot of haywakuy and Ankashchaki stopped kidnapping people. [Martin, Q64, Marcachea]

According to the Q'eros, there are cities inside the apus and you can reach them through the holes in the rock (punkus). However, this is not possible for every human being. Only altomesayoq are able to enter the interior of the apus. From the above story, it can be concluded that time in the underground world runs differently. When the girl returned to the human world, she was much older and changed. From Martin's tales we hear that apu Ankashchaki had been neglected by people in ancient times, and it was the reason why he became predatory and dangerous for the inhabitants of the village, i.e. he was kidnapping their children and animals. After the intervention of the altomesayoq, who completed a series of haywakuy, apu Ankashchaki ceased to threaten people. Interestingly, the Q'eros also said that, in the past, great altomesayoq could enter the point (holes in the rocks) to travel. Rolando, who came from Esparilla (Marcachea annex), said the shamans were entering a gateway near their villages and coming out on the other side of the mountain range near Cuzco. Altomesayoq also communicated with apus for the purpose of multiplication of animals. They were going inside the mountains and negotiating with the apus (rulers of animals), who, following the performance of appropriate rituals, gave them animal herds. Rolando commented:

Andres Pauccar was one of the biggest Q'eros altomesayoq, he negotiated with ghosts, he went into the underground world and from there he brought cows, people know about it. Negotiated with Qolquepampa and with many other apus and wak'as. His son was Domingo Pauccar, who lived in Q'ero Totorani, he was a great man. Juan Pauccar was Domingo's son, he lived in Hatun Q'eros and his son was my father, then me. We are the seventh generation of paqos. [Rolando, Q41, Esparilla]

The above stories illustrate the concept of goods exchange between people and non-humans. However, when relationships between people and non-humans are broken, hungry apus, not provided with food, become predators who must take care of themselves. For this purpose, they kidnap animals and humans. In other cases, when a human consciously or unconsciously appropriates an animal which is owned by apus, they also could kidnap or kill people. This could mean that non-humans try to compensate for their losses of resources through acts of aggression against people. Rolando, originating from the paqos family, also told me about the altomesayoq trip to the interior of the apus: 
My grandmother from the father's side lived underground for 6 months, because apus took her there. Altomesayoq managed to save her after 6 months, and she survived.

\section{Did she also disappear physically?}

Completely, physically. Altomesayoq saved her. First, altomesayoq from the village went there to see where she was, in what place, then they looked for the best altomesayoq and they went to save her. They made haywakuy rituals and set when she would come out. The apus said that she would come out after three strokes of bells. The first hit in the mountains was heard, tannn, and smoke came out from the top of the mountain. The second hit, tannnn, her body appeared halfway, after three strokes the whole of her appeared. Then two wallata [kind of bird], who were also involved in it, took her by hands and brought her flying to Pollani, then gave her to the bull and the bull brought her. They used animals to deliver her, because it was a mountain that you could not enter. She was still small, she was six-seven years old.

Does she remember about this event?

Yes, she told ... how the apus left her, my grandmother looked like a wild animal, she did not want to be touched. However, they managed to catch and tie her, kept her at home, but she cried a lot, because she could not get accustomed to her parents. She only wanted to be among animals, with birds, with cows, with llamas. So, she was always tied at home, for a long time. Then she got accustomed to it and met my grandfather and they started to live together. My grandmother told me that when she lived underground, there were towns like here, there were a lot of cows, houses and shops. She said that she was grazing cows there and milking them. She was doing that. The sun was different, as if it were a light bulb that did not illuminate much. Then she died young, she was 35-36 years old. There were many people from Q'eros who visited the underground worlds, including Maria Apasa, who was altomesayoq, she was also there many times. (...) And it was not a dream, an illusion, it really happened. [Rolando Q30, Esparilla]

It should be noted that the little girl came back to the human world in a changed state, her behavior resembled that of a wild animal. A certain transformation of the girl's behavior occurred, and she ceased to speak in a human voice, she was screaming and behaving like a non-human. It is also worth pointing out that, in this story as well the apus are rulers of wild animals. This leads to the conclusion that apus and their interior (underground world) is understood by the Q'eros as a wild (uncivilized) and untamed space. It should be noted that a longer contact with this wild world leads to a transformation, which is, however, reversible.

\section{Apus and shape-shifting}

Another of the key characteristics of apus is that they can communicate with people, usually with paqos, or shamans. But how? They can do it directly, by taking on human form, or indirectly, through their envoys (birds). Q'eros communities 
tell a lot of stories about apus who reveal themselves in the human form. Most often, the apus will appear in the masculine form (an old man with a gray long beard), but they can also take the form of a woman. Interestingly, the apus (both in dreams and in reality) appear in the form of people who are in some way associated with power and high status - they can be policemen, soldiers, old white men, landlords, colonists. Based on this observation, it can be concluded that the apus enjoy higher status than people, which also reveals their exceptional skills and agency. The following fragment of the conversation with Ana Maria (from Quico) illustrates the transformation of apus into people:

I was 13 years old. In those days, there were no roads, no cars, you had to walk ... I went on a journey with my aunt. There was a point where you had to wait, where horses were rented to go on.... And one time, a very strong wind blew, whistling and strong wind. I thought there was going to be a storm or a hurricane. And people were shouting: "run away, run away, just hide". And I will never forget it. I heard: "go down, go down". But I just waited, waited ... and saw a great condor who flew in my direction.

And how do you understand it?

At that moment it seemed to me that time had stopped. It was an old condor, we call him awki. He is the boss of all condors. I saw his face, eyes, everything. As they say: It's time. He [condor] turned back and flew the other way. He showed me the way, he flew towards Ausangate. Ten minutes passed, and then people came and asked: what did he do to you? Nothing, why? - I answered. Why did not you run away, he could have killed you. But no, these people were afraid. And they told me: it is time, your time has come. But I did not understand what it meant.

\section{Did they also see this condor?}

They saw, they asked why I did not run away, and they said that he was looking for food. No, he came to greet me. We walked for a four-five hour to a hut, where my parents' family lived. There was a lagoon there, I wanted to see the condors, because I felt they were calling me. But I could not go because I needed someone to go with me. And that night, it was like a connection between grandparents and parents. I came home and I rested. My family told me that they had heard a noise during the night, but I did not because I was sleeping soundly. The next day, the uncles woke me up and said, "you know what, your grandfather and father came in at night". And they said to my uncles: "How is it possible that you receive my daughter in this way, I want you to change. I want the best for you. This is not a place for her".

Apus said it to ...

My uncle, but in the form of close relatives. My uncle was afraid because my grandfather was already dead. [Ana María, Z12, Cusco]

The story quoted above indicates that the woman met with the condor who was the messenger of the $a p u$. The apu appeared in the form of humans - relatives 
of the girl (the girl's father was then far away, and the grandfather was dead). According to the Q'eros, apus come to people in a human form to give them a message. Sometimes they appear to inform about the shamanic mission with which a person is to be entrusted. The following excerpt from the conversation with Florentino illustrates such a situation:

\begin{abstract}
They say that apus appear in the form of humans?
Of course, I saw them too. Ausangate is an old man and has a long beard, white, he is tall and powerful. His clothes are like from another world, are very delicate, very special. Earlier, our ancestors were more connected [with apus], knew them better, knew the function of each mountain. They talked to them all the time. The apus are also owners of animals, condors, pumas and vicunas. The condors are animals of collana apus [awki, boss]. Smaller birds belong to payan and cayao. For example, waman [falcon] is their messenger [apus], just like anqa [eagle]. The most important is the condor, then the eagle, then the falcon. The falcon is smaller and quick, that is why he is an envoy, he is fast, he looks after villages, he reports what happened or what will happen. Paqos can learn from them and read their messages, hear their voice, or learn through their visions, so they already know what happened. They advise their people, their villages. [Florentino, Q17, Marcachea]
\end{abstract}

The shaman Florentino also told me that he saw apu Antipukara near Marcachea village. Antipukara walked through the mountain in the company of his dog, in the form of an old man who supported himself with a cane and had a hat on his head. At the foot of Antipukara there is a small lake Yana Qocha (Black Lake), from which he drinks every day, and during the drought the lake dries out and then Antipukara suffers from thirst. Seeing apus in the human form is an extraordinary event. The apus appear to altomesayoq in the human form while the person is awake or during sleep. It is worth noting that healing rituals for patients always take place in the dark, because the apus do not want to be observed by people and they reveal their presence only through movement and voices. The Q'eros also claimed that only altomisayoq can see apus in a variety of forms - it can be a condor, an eagle or a pigeon. Hiroyasu Tomoeda (1992: 196), in the context of the village of Kuyo Grande (Pisaq-Calca), wrote that in some cases the form may also be that of a white, bearded man or an angel. Martin from Marcachea told me:

A young man who took part in this was very rebellious. He illuminated the altar with a torch just out of curiosity. And we saw a white pigeon. The apu pushed the young man outside ... as if somebody was pushing him. The apu pushed him outside as if he were a strong person. He felt it in that way. But it was the apu. He hit him with a whip. He pushed him outside, so he would not play with him. This pigeon was the apu, called by Paqo Julian of Chuwa Chuwa. I was 16 at the time. My sister Maria, Armando's mother, took me there to ask about our father (...) [Martin, Q36, Marcachea] 
Paqo Toribio also talked about the consequences of his curiosity during the ritual:

Once, I saw a bird and they [apus] told me: Look, boy, you will not look at me, go away. "I had to leave, I was about 14 years old. You cannot look at them. [Toribio, Q70, Hatun Q'ero]

The last, rather peculiar, fragment of the description shows apus not in the form of people, but small moving stones that resemble dwarfs:

Apus come to altomesayog and beat them with whips, ufff, strongly. When my first daughter was born, Maria's great-granddaughter, my wife could not ... she could not give birth for almost two days ... She almost died, so I went all the way to Saqarara to find Maria and I gave her coca leaves, a bottle of alcohol and said: "My wife is not doing well". And I told her everything. And she gave me her poncho and said, "Take cover, boy. I will call the apus" she said. It was at 10 a.m. -11 a.m., there was a cave there. But I saw something, they came as stones, small as gnomes and birds, and they said: "Son, do not look/Ama qhaqankichu. You will have sick eyes/Ñawijkita onqonchiranku". She sat there with her open altar. "Your child was born. It's a girl," Maria said. "So'qa wayra [wind of ancestors] came and caught her and did not allow her to give birth. They have already taken it. A machula [dead] was crying and saying, "I want to take her," but the apus found out and took him away. [Victor, Q91, Quico]

As we can see, looking at apus is dangerous and usually ends badly for a human - who is physically punished. The apus can also communicate with people through dreams. Torres Lezama indicated that people do not dream about apus, but that apus make people dream about them, because people say "taytacha musqhoychawan" - the meaning of this expression indicates that apus caused a dream. The content of a dream is understood by the Q'eros as a message from non-humans. In dreams, these non-human persons take the form of various figures - policemen, old women, soldiers, or children.

\section{Apus as healers}

The most pronounced expression of reciprocity and feeding is the haywakuy ritual. In Quechua language haywakuy ${ }^{8}$ means literally: give something to someone with reciprocity or share something. Studies show that it is a polysemantic ritual (e.g. Bolton, Bolton 1976; Allen 1988; Greenway 1998; Lorente Fernández 2010). As I mentioned earlier, this ritual takes a collective form in August (the beginning of the agricultural year) when pachamamas must regenerate forces to be able to bear

\footnotetext{
${ }^{8}$ Called also despacho, mesa, (in Spanish language); anthropologists translate this as: offering ceremony, offering bundle, burned offerings.
} 
fruit in the following year; and during the carnival (puhllay), to ensure good health and breeding of animals. It was also mentioned that the Q'eros perform haywakuy individually, asking for health, happiness, love, work, etc. The ritual is also necessary in case of adverse weather, animal diseases, indeterminates, during weddings, construction of a new house or to resolve disputes. Therefore, haywakuy also functions as a protective ritual. I, as an outsider, performed it when I visited the village for the first time, or when I returned there after a long absence. The Q'eros claim that strangers must "say hello" to non-human entities and ask them for a kind of "residence permit". As I mentioned in the introduction the Q'eros explain that a visitor should ask non-humans for permission to enter the village and also give them a gift, as in the case of social visits. This idea emphasizes the person-like status of apus, their protective role and close relationship between them and humans. During my research, I performed this ritual many times in different contexts (healing, request for good luck on the journey or for the success of my project, request to grant me permission to enter the village, to prevent attacks from dangerous non-humans). Although its parts may have changed depending on the recipient, the structure and the meaning of the ritual remained the same. Each ritual begins by reading from the leaves of $\operatorname{coca}^{9}$ - to identify the problem, the causes of the disease, the method of treatment, the ingredients, the addressee to whom the victim should refer, and how to deliver the offering. The shaman invokes the patient's guardian apus and pachamamas (tirakunas) animated spaces related to your birth place and actual residence. It should be noted that the terms pachamamas and tirakunas ${ }^{10}$ are in plural - which indicates that Pachamama (often referred to as the Mother Earth) should be understood as a non-human person (animated spaces) with whom humans establish a network of relationships throughout their lives.

In the next step, the paqo (shaman) invites the non-people to coca leaves chewing (pijchay) and libation ritual (ch'allay), serving them wine and beer. He prepares all attributes (bell, sleeve made of vicuna leg skin/fur ${ }^{11}$ and altar) and stars to form a bundle. First, he spreads white paper on the altar (symbolizing the plate) and then, in the middle, puts cotton symbolizing Hanan Pacha (the upper world). Then, he lays the circle of petals of white and red cloves and forms the patient's body (my body) with coca leaves (k'intus) onto which the patient blows three times (passing his living energy - samay). Simultaneously, the patient asks apus not only to grant them good health, but also work, money, love, happiness, prosperity for themselves and their families. This reveals the holistic (many elements) and collective (me and family) health dimension in Q'eros ontology. After that the paqo sequentially lays the following elements on the left-hand side (for pachamamas) and right-hand side (for apus):

\footnotetext{
${ }_{9}^{9}$ See (Przytomska 2013-2014, 2015).

${ }_{10}$ The Q' eros use the term tirakunas to describe pachamamas, and not all non-human persons.

${ }^{11}$ Shamanic attribute.
} 


\begin{tabular}{|l|l|}
\hline \multicolumn{1}{|c|}{ PACHAMAMAS (female) } & \multicolumn{1}{c|}{ APUS (male) } \\
\hline $\begin{array}{l}\text { Coke grains, chickpeas, (health) } \\
\text { Cereals, red corn, lentils, figs } \\
\text { (abundance) }\end{array}$ & Lama fat, white sugar, chickpeas, wiraq'oya \\
herb, quinoa, rice (health) \\
Anise (communication) & Incense, yellow corn (money) \\
Sweet biscuits (harmony) & Wheat, lentils (abundance) \\
Peanuts (care) & Anise (good communication and harmony) \\
& Pasta (family harmony) \\
& Beans (happiness) \\
\hline
\end{tabular}

Each of these elements is, at the same time, a gift (meal) for non-humans and an equivalent of wishes to be fulfilled e.g. chickpeas as a gift to pachamama, is to be reciprocated in the form of health, etc. This leads to the conclusion that haywakuy should not be understood as a sacrificial ritual (gift), but as ayni (Quechua concept of reciprocity), where each donated element will be reciprocated. When I asked Toribio (the shaman from Hatun Q'ero) if haywakuy could be conducted without asking for something in return, he replied, "no, you always have to ask for something in return", which clearly indicates the imperative of reciprocity.

After preparing the bundle, the shaman wraps it up with white paper and a string, after which the bundle should be burned. If a lot of smoke is released and the ash is white, it means that non-humans are happy with the gift. If the shaman does not meet their expectations, he will face punishment - e.g. illness, accident, whipping. Burning haywakuy is an important part of the ritual and is a process of the gift delivering to the apus who, in an act of reciprocity, treat the patient. The final step of the treatment process is a waqay (soul calling). The shaman lifts his altar and makes it move from top to bottom along the patient's body. Then, he places the altar on the patient's head and says: "come soul, come." In the end, he blows three times at the tip of the patient's head, which is the place where the soul enters back into the body.

In conclusion, haywakuy is an act of feeding non-humans (apus, pachamamas) by the shaman (and the people he represents). According to the Q'eros, haywakuy is not, strictly speaking, 'feeding', but a process of mutuality: the shaman feeds non-people who, in an act of reciprocity, give people good health and prosperity. As the Q'eros point out, people's well-being depends on the well-being of non-humans, and vice versa.

Apus also perform healing sessions with the help of altomesayoq (shamans), who can talk and call their apus in important situations. Jorge, the nephew of Maria Apasa, said:

My aunt, María Apasa, people who were robbed came to her. Someone went to their home and robbed them. So, my aunt tells you exactly who came into your home. My aunt brings her altar and calls the apus with coca leaves. And within 20 minutes, 30 minutes they come. They enter the house, make the noise like pum, pum, pum, in this way and they talk, they ask what they are doing here, why were 
called. Maria gives them food. The person tells what happened and say: "Tayta [father], tell me who robbed me". And then they [apus] tell you who robbed you or where you can find what you have lost. Or they say: "Wait, you will find out in a while", or say that you will not find it, that you will lose it, that you will not be able to recover it". Altomesayoq is unique. [Jorge, Q31, Ocongate]

My uncle, Manuel Quispe, and my grandfather were altomesayoq, they were able to talk with apus. For example, if you want to meet your grandmother who died, altomesayoq calls your grandma, you just must give him her full name. Apus come and bring your grandma and you can hear her voice, you can talk to her. Apus come and speak in your language, in the same voice as your grandmother: "how are you my daughter?", he says. To my uncle, Manuel Quispe, people came and say: my son is sick, heal him, help him. So always in the dark my grandfather called for apus to help him cure people. People came, and I was little and curious, so I sat in a corner of the room and watched. It was completely dark, but once I tried to see something, then [apus] they said to me: why are you looking at me? Close your eyes, son. [Toribio, Q50, Hatun Q'ero]

Shamans invoke apus to treat patients and to read the future and the past, and their relationship is based on reciprocity. Conversations with apus are held at night and in the dark, because looking at apus is forbidden. The shaman evokes apus, which come in the form of birds (pigeon, condor, owl, seagull) or wind. Their presence is felt by the flutter of the wings and the sound of claws. The shaman prepares ch'allay for the apus, made of wine and aqha (maize wine). The apus help themselves to alcohol and greet people. They present themselves, for example: I am apus Ausangate, why did you summon me? The Q'eros say that an apu is usually a bit irritated, because he or she was interrupted and keen to return to his or her duties. Then, the apu answers questions and treats the patient. Victor from the village of Quico talks about his experiences:

Martin Quispe always called apus in the dark and at midnight. Condors were coming and pachamama was coming under the figure of the wind. When you are guilty or make fun of it, or if you do not do it from the heart [apus] they start talking to you, for example: Ana, are you mocking us? And they beat you with a whip. Ausangate, Kikukuchu, Wamanlipa come, various apus come. They sit in different places and drink their wine. [Victor, Q100, Quico]

Apus help in the ritual, which is called kutichiy, it consists of banishing the disease out of the patient's body. Before the ritual paqos put wayruru and sullukuti seed on the altar - both of these seeds belong to the kuti plant group. Kutichiy means in quechua "to give back, to pay back". The ritual consists in removing the disease from the patient's body and putting it back in its place, its place of origin. In another case, kutichiy may refer to witchcraft, and in this context, it means returning the disease to a layqa or layqa's client, i.e. a sorcerer who cast 
the bad spell, i.e. caused the disease. The Q'eros claim that you cannot get rid of the disease, it is alive and has a personal nature. Therefore, a kutichiy ritual is performed to return the disease, during which altomesayoq yells: "fuera, fuera, fuera/ out, out, out", and beats the patient with a whip. Toribio imitates the voice of wayra (wind) diseases "aaaaa, waaa, waaa" - screams the wounded wayra. Only then, you can call the patient's animu (kind of soul). As we have seen, the kutichiy ritual is also based on reciprocity (ayni) concept, in this context, it takes the form of giving something negative and destructive (e.g. illness).

\section{Conclusion: apus as non-humans}

In Q'eros ontology, different elements of nature are perceived as personal beings. An example is apus, i.e. mountain-people who surround Andean villages and keep a close eye on the monotonous life of the inhabitants. After all, for the Q'eros, these are not just terrain formation, but beings that affect their lives: they are guardians of shamans and villages, rulers of wild animals and minerals and healers. These beings are not only in constant contact with the inhabitants of villages (through shamans) and take care of the health and well-being of these people, but they also participate in important political and social events (the fight against hacendados or participation in liberation wars and the war of the Pacific). This means that they play an active part of these people's stories. On the one hand, they are not human, but on the other hand they are similar to humans, because they lead a similar lifestyle and have similar needs and desires. Of all non-human beings in Q'eros ontology, apus are characterized by the greatest degree of agency, as indicated by the examples described in the text.

According to the Q'eros' myths, in ancient times (ñawpa pacha) pre-humans possessed apus-like skills, but due to bad behavior they lost them, as a punishment sent by viracochas - cultural heroes (Przytomska 2013-2014). The Q'eros comment, among others, that apus are the guardians of people and villages (e.g. Greenway 1998). Therefore, some researchers identify them with guardian deities, saints or compare them to angels (e.g. Marzal 1985; Saldaña Sousa 2017), and define relationships between people and apus as a kind of religious worship, which represents protection. According to the definition of Philippe Descola (2013: 325-329), the protection relationship is a one-sided (asymmetric) act that does not involve a reciprocating movement by the protected party. The protection relationship is characterized by dominance between the superior and the subordinate, which is initiated by initiated by the former (superior), with the latter (subordinate) unable to reject this relationship. A gift, on the other hand, is an example of positive asymmetry, where entity A offers something to entity B without waiting for anything in return ${ }^{12}$.

\footnotetext{
${ }^{12}$ It should be noted that Descola (2013: 311-314) proposes his own concepts of reciprocity (exchange) and gift, thereby rewriting the well-known concepts of Marshal Sahlins (1972) and Marcel Mauss (1973). He distinguishes the concepts of gift and exchange. In their approach,
} 
In my opinion, such a scheme is not sufficient to describe the relationship between humans and non-humans in Q'eros ontology. For the Q'eros, the relationship between humans and non-humans consists in the transfer of vital substances, which is expressed by terms related to "feeding each other" (reciprocity scheme) or "feeding someone" (predatory scheme).

Reciprocity scheme, which in Q'eros ontology is expressed by the indigenous idiom of ayni, present between apus and humans in what we observe in the haywakuy ritual. This ritual consisting in mutual feeding is understood as an example of building relationships, but also becoming human (in Quechua runa) and building humanity. The one who does not act according to ayni is not a full human in Andean ontology. The reciprocity scheme is the ethos of the Q'eros (and other Quechua), i.e. a scheme that dominates their ontology in relation to all beings (human and non-human). These practices form a collective community made of humans and non-humans who need each other to function properly. Apus must be fed by humans (sacrificial rituals) and people must be fed by apus and other beings (pachamamas).

The Q'eros said that as the consequence of abandoning ritual practices (feeding), a non-human being becomes wild and predatory towards humans. This situation is manifested by attacks that aim to eat the victim without giving something in return. This is called a predatory scheme (which, however, does not have its equivalent in Quechua). Interestingly, predatory appears where reciprocity has been abandoned, so it is a secondary scheme, but often present. For the Q'eros, most predatory behaviours of people and non-humans are associated with dehumanization (loss of rune status) - a disease or a transformation. Apus that have ceased to be fed by humans become hungry, for this reason they begin to attack people and "eat" them - sucking their vitality or depriving them of yields and animals. It is not only mountains that can became predators, but also the dead, who have been forgotten by humans. If people stopped feeding them with haywakuy, they would become the target of their predatory attacks. Every human activity has its consequences in a complex chain of relationships.

\section{Acknowledgement}

For their insights, I am especially grateful to Aleksander Posern-Zieliński, Mariusz Ziółkowski, Dominika Sieczkowska, Adrián Gonzalez La Civita, and the anonymous reviewers of this paper.

the gift includes the imperative of reciprocity, but Descola treats these two types of relationships as two different phenomena, where the gift is an unselfish one-way act that does not imply giving anything back. 


\section{References}

Abercrombie, T. (1998). Pathways of memory and power. Ethnography and History among and Andean People. Madison: University of Wisconsin Press.

Alderman, J. (2015). Mountains as actors in the Bolivian Andes: The interrelationship between politics and ritual in the Kallawaya ayllus. The Unfamiliar, 5(1\&2), 33-45.

Allen, C. (1982). Body and Soul in Quechua Thought. Journal of Latin American Studies, 8(2), 179-196.

Allen, C. (1988). The Hold Life Has: Coca and Cultural Identity in an Andean Community. Washington: Smithsonian Books.

Allen, C. (2016). The Living Ones: Miniatures and Animation in the Andes. Jouranl of Anthropological Research, 72(4), 416-441.

Avendaño, H. (1648). Sermones de los misterios de nuestra Santa Fe Católica, en lengua castellana y la general del Inca. [Accessed on 1.05.2019: https://archive.org/details/ sermonesdelosmis00aven/page/n4].

Astvaldsson, A. (2000). Las voces de los wak'a: Fuentes principales del poder político aymara. La Paz: CILCA.

Barrionuevo, B. (2011). Hablando con los Apus. Poder en los Andes: la fuerza de los cerros. Lima: Nerit Olaya Guerrero.

Bolin, I. (1998). Rituals of Respect: The Secret of Survival in the High Peruvian Andes. Austin: University of Texas Press.

Casaverde Rojas, J. (1970). El mundo sobrenatural en una Comunidad. Allpanchis, 2(2), 121-243.

De la Cadena, M. (2015). Earth Beings: Ecologies of Practice Across Andean Worlds. Durham: Duke University Press.

Descola, P., Pálsson, G. (eds.). (1996). Nature and Society. Anthropological Perspectives. London, New York: Routledge.

Descola, P. (1992). Society of nature and the nature of society. In: A. Kuper (ed.), Conceptualizing society (p. 107-126). London, New York: Routledge.

Descola, P. (1996). Constructing natures: Symbolic ecology and social practice. In: P. Descola, G. Palsson (eds.). Nature and society. Anthropological perspectives (p. 82-102). London, New York: Routledge.

Descola, P. (2013). Beyond Nature and Culture. Chicago: University of Chicago Press.

Favre, H. (1967). Tayta Wamani: Le culte des montagnes dans le centre sud des Andes péruviennes. Nouvelle Série, 61, 121-140.

Fernández Juárez, G. (2004). Yatiris y ch'amakanis del altiplano aymara. Sueños, testimonios y prácticas ceremoniales. Quito: Abya-Yala.

Fuenzalinda, F. (1965). Santiago y el wamani: Aspecto de un culto pagano en Moya. Debates en Antropologia, 5, 155-188.

García, G. (2012). La comunión de los cerros. Ritualidad y ordenamiento simbólico del paisaje en una comunidad del Altiplano Sur Andino. Diálogo Andino. Revista de Historia, Geografía y Cultura Andina, 39, 39-55.

Gose, P. (1986). Sacrifice and the commodity form in the Andes. Man, 21, 296-310.

Gose, P. (1994). Deathly Waters and Hungry Mountains: Agrarian Ritual and Class Formation in an Andean Town. Toronto: University of Toronto Press.

Gose, P. (2001). Aguas mortíferas y cerros hambrientos. Rito agrario y formación de clases en un pueblo andino. La Paz: Ediciones Abya-Yala. 
Gose, P. (2006). Mountains Historicized: Ancestors and landscape in the Colonial Andes. In: P. Dransart (ed.), Kay Pacha: Cultivating earth and water in the Andes. BAR International Series 1478, Oxford: Archaeopress.

Greenway, Ch. (1998). Hungry earth and vengeful stars: Soul loss and identity in Peruvian Andes. Soc. Sci. Med., 48/8, 993-1004.

Hallowell, I. (1976). Ojibwa Ontology, Behavior, and World View. In: Contributions to Anthropology: Selected Papers of A. Irving Hallowell (pp. 357-390). Chicago: University of Chicago Press.

Horigan, S. (1988). Nature and Culture in Western Discourses. London: Routledge.

Howell, S. (1996). Nature in Culture or Culture in Nature? Chewong Ideas of 'Humans' and Other Species. In: P. Descola, G. Pálsson (eds.), Nature and Society: Anthropological Perspectives (p. 127-144). Londyn, Nowy Jork: Routledge.

Ingold, T. (1988). Introduction. In: T. Ingold (ed.), What is an Animal? (p. 1-16). London, New York: Routledge.

Ingold, T. (1993). Building, Dwelling, Living: How Animals and People Make Themselves at Home in the World. ASA Decennial Conference.

Isbell, B.J. (1978). To Defend Ourselves: Ecology and Ritual in an Andean Village. Austin: University of Texas Press.

Latour, B. (1994). We Have Never Been Modern. Cambridge, Harvard: Harvard University Press.

Kohn, E. (2013). How Forests Think: Toward an Anthropology Beyond the Human. Berkeley: University of California Press.

Lévi-Strauss, C. (1964). Les mythologiques: Le cru et le cuit. Paryż: Plon.

Lévi-Strauss, C. (1972). Structuralism and Ecology, Gildersleeve Conference. Barnard College.

Martínez, G. (1983). Los dioses de los cerros en los Andes. Journal de la société des américanistes, 69, 85-115.

Marzal, M. (1983). La transformación religiosa peruana. Lima: PUCP.

Marzal, M. (1985). El sincretismo iberoamericano. Lima: PUCP.

Mauss, M. (1973). Szkic o darze. Forma i podstawa wymiany w społecznościach archaicznych. Warszawa: PWN.

Mendizábal, E. (1989). Estructura y función en la cultura andina. Lima: Editorial de la Universidad Nacional Mayor de San Marcos.

Milton, K. (1993). Environmentalism: the View from Anthropology. London: Routledge.

Przytomska, A. (2013-2014). Kukata Yachan. La coca en la cosmovisión de los q'eros. Estudios Latinoamericanos, 33-34, 307-325.

Przytomska, A. (2017). "Hay que alimentar a la Madre Tierra". Haywakuy: un ritual de sanación e intercambio en la ontología de los q'eros. In: V. Torre, V. Anguiano (eds.), Recuperando la vida: Etnografías de sanación en Perú y México (p. 113-138). Lima: Ríos Profundos editores.

Ricard Lanata, X. (2007). Ladrones de sombra. El universo religioso de los pastores del Ausangate (Andes surperuanos). Paris: Institut français d'études andines.

Rival, L. (1966). Blowpipes and spears. The social significance of Huaorani technological choices. In: P. Descola, G. Palsson (eds.), Nature and society. Anthropological perspectives (p. 145-164). London, New York: Routledge.

Rosset, C. (1973). L'anti-nature: Elements pour une Philosophie Tragique. Paris: PUF.

Rosas Lauro, C. (2014). Curanderos, chamanes e idólatras en los Andes. Una perspectiva histórica de larga duración. In: C. Rosas Lauro, O. Velásquez Benites (eds.), Por la mano del hombre. Prácticas y creencias sobre chamanismo y curandería en México y el Perú (p. 29-65). Lima: Asamblea Nacional de Rectores. 
Rozas Alvarez, J.W. (1992). “Sana, sana patita de rana...". In: H. Tomoeda, J. A. Flores Ochoa (eds.), El Qosqo. Antropología de la ciudad Cuzco (p. 199-224). Cuzco: CEAS, Ministerio Educación de Japón.

Rösing, I. (1995). La deuda de ofrenda: un concepto central de la religión andina. Revista Andina, 12(1), 191-216.

Sahlins, M. (1972). Stone Age Economics. Chicago: Aldine-Atherton.

Saldaña Sousa, C. (2017). Los Apus: configuración etnomédica en Perú actual. Salamanca: Ediciones Universidad Salamanca.

Sánchez Garrafa, R. (1999). Wakas y apus de Pamparaqay. Estructuras simbólicas en la tradición oral de Grau-Apurímac. Lima: Optimice Editores.

Sánchez Garrafa, R. (2015). Apus de los cuatro Suyus. Construcción del mundo en los ciclos mitología de las deidades montaña. Lima: IEP.

Sax, M. (2011). An ethnography of feeding, perception and place in the Peruvian Andes (where hungry spirits bring illness and wellbeing). New York: Edwin Mellen Press.

Stobart, H. (2006). Music and the Poetics of Production in the Bolivian Andes. London: Routledge.

Strathern, M. (1980). No nature, no culture: the Hagen case. In: C. MacCormack, M. Strathern (eds). Nature, Culture and Gender (pp. 174-222). Cambridge: Cambridge University Press.

Tomoeda, H. (1992). Curanderos Urbanos: Salud y ritual en el Cuzco contemporáneo. In: H. Tomoeda, J.A. Flores Ochoa (eds). El Qosqo. Antropología de la ciudad (p. 188-198). Cuzco: CEAS, Ministerio Educación de Japón.

Torres Lezama, V. (2017). Cuerpo, animu y alma como integridad en la persona andina. In: V. Torres Lezama, V. Anguiano (eds.), Recuperando la vida. Etnografías de sanación en Perú y México (p. 33-74). Lima: Río s Profundos editores.

Valderrama, R., Escalante, C. (2012). Montañas sagradas y rituales en los andes. In: J. W. Rozas, D. Valencia (eds.), Cultura Andina. Cosmovisión, arqueología. Cusco: Funsaac.

Valderrama, R., Escalante, C. (1979). Gregorio Condori Mamani. Autobiografía. Cuzco: CBC.

Viveiros de Castro, E. (1992). From the Enemy's Point of View: Humanity and Divinity in an Amazonian Society. Chicago: University of Chicago Press.

Willis, R. (1990). Introduction. In: R. Willis (ed.), Signifying Animals: Human Meaning in the Natural World. London: Routledge.

Zuidema, T. (1977). Mito e historia en el antiguo Perú. Allpanchis, 10, 15-52.

\section{SUMMARY}

Apus: Non-human persons in the ontology of the Q'eros from the Cordillera Vilcanota (Peru)

The villages of the Q'eros (local Quechua group from the Vilcanota mountain range) are surrounded by high mountains (apus) that seem to observe the monotonous life of the inhabitants. After all, for the Q'eros, apus are not only a form of terrain, but also person-like beings that have an impact on daily human lives. Apus (mountain-person) are described as the guardians of villages, as wild animal masters; mineral and precious stones masters, healers and the guardians of shamans. In the text we analyze the ontological status of apus as non-human persons, the impact of apus on human lives and relationships between humans and apus that rely on reciprocity or predation.

Key words: Quechua, Andean ontology, apus, Q'eros, shamanism, anthropology of nature 